\title{
Effect of Immune Globulin Intravenous on Opsonization of Bacteria by Classic and Alternative Complement Pathways in Premature Serum
}

\author{
MEN-FANG SHAIO, KUENDER D. YANG, JOHN F. BOHNSACK, AND HARRY R. HILL \\ Departments of Parasitology and Tropical Medicine, Pediatrics, National Defense Medical Center, Taipei, \\ Taiwan, Republic of China; Division of Clinical Immunology and Allergy, Departments of Pediatrics and \\ Pathology, University of Utah School of Medicine, Salt Lake City, UT 84132
}

\begin{abstract}
The mechanisms involved in the effect of immune globulin intravenous (IGIV) on bacterial opsonization by both complement pathways in premature serum were elucidated in this study. Of the bacteria used, Staphylococcus aureus and Salmonella enteritidis were nonencapsulated while Streptococcus pyogenes and Escherichia coli $07 \mathrm{~K} 1$ were encapsulated. As demonstrated by indirect immunofluorescence, IGIV showed specific antibody titers of $1: 32$ for $S$. aureus and $S$. enteritidis and of $1: 8$ for $S$. pyogenes and $E$. coli 07 K1. IGIV alone had no direct opsonic activity against these organisms. Addition of IGIV did not alter the opsonic activity of normal adult serum against these organisms. In contrast, addition of IGIV promoted the opsonic activity of premature serum against the nonencapsulated bacteria to levels matching that in normal adult serum. The IGIV preparation significantly improved the opsonization of bacteria by the classic (from 39 to $68 \%$ of that in adult serum) and alternative (from 22 to $97 \%$ of that in adult serum) complement pathways in premature serum. IGIV also markedly augmented C3 deposition on the bacteria by both complement pathways. These studies suggest that IGIV containing high titers of specific antibodies promote opsonization of bacteria by the enhancement of complement pathway activation, especially the alternative pathway, in premature serum. (Pediatr Res 25: 634-640)
\end{abstract}

\section{Abbreviations}

IGIV, immune globulin intravenous

CCP, classic complement pathway

ACP, alternative complement pathway

$\mathrm{CH}_{50}$, hemolytic unit of classic complement pathway activity

$\mathbf{A P}_{50}$, hemolytic unit of alternative complement pathway activity

CR1, complement receptor type 1

CR3, complement receptor type 3

HBSS, Hanks' balanced salt solution

CFU, colony-forming units

Received February 29, 1988; accepted January 15, 1989.

Correspondence and reprint requests Men-Fang Shaio, Department of Parasitology and Tropical Medicine, National Defense Medical Center, Taipei, Taiwan, Republic of China.

Supported in part by Grants NSC 760412-B01614 and NSC 780412-B01612 from the National Science Council, Taiwan, R. O. C (M-F. S.), and Grants AI 13150 and AI 19094 from the National Institute of Allergy and Infectious Diseases (H. R. H.).
Opsonophagocytosis is one of the most important host defense mechanisms against bacterial infection. Optimal opsonophagocytosis of bacteria depends on the presence of both heat-stable (antibodies) and heat-labile (complement) opsonins (1). Severe and recurrent bacterial infections commonly occur in patients with humoral immunodeficiency. In patients with hypogammaglobulinemia, the use of IGIV has been shown to be effective in preventing bacterial infection (2-4).

A defect in opsonic defense to bacteria has been well documented in premature neonates (5). This deficiency is attributable to lack of effective antibodies and low complement activity (5). Recently, a number of investigators have suggested that IGIV is beneficial in the prevention or treatment of sepsis in premature and low birth wt neonates (6-8). Although IGIV contains antibodies direct against most of the common bacterial pathogens, complement is often necessary for optimal uptake and killing of bacteria by neutrophils (9). The purpose of this study was to determine the effects of IGIV on the opsonophagocytosis of bacteria by both complement pathways in premature infant serum.

\section{MATERIALS AND METHODS}

Bacterial strains and culture conditions. Both gram-negative and gram-positive, encapsulated or nonencapsulated bacteria, were used in this study. Staphylococcus aureus (NCTC6571), Salmonella enteritidis (NCTC6676), Streptococcus pyogenes (NCTC8199), and Escherichia coli 07 Kl (E39916) were obtained from Central Public Health Laboratory, London, England. Each strain was preserved in $12 \%$ glycerol in small aliquots at $-70^{\circ} \mathrm{C}$. In studies of phagocytosis, each strain of bacteria was grown at $37^{\circ} \mathrm{C}$ in Muller-Hinton broth (Difco Laboratory Co., Detroit, MI) with or without $0.02 \mathrm{mCi}$ of $\left[{ }^{3} \mathrm{H}\right]$ thymidine $(\mathrm{sp}$ act:6.7 Ci/mmol; ICN Radiochemical, CA) for $15 \mathrm{~h}$. The organisms were washed and suspended in PBS (pH 7.4) at $2 \times 10^{8}$ $\mathrm{CFU} / \mathrm{ml}$ as determined by a spectrophotometer at $620 \mathrm{~nm}$ wavelength.

Serum preparations. Venous blood from 12 healthy adult volunteers was allowed to clot at room temperature for $0.5 \mathrm{~h}$. After centrifugation, these sera were pooled as normal adult serum and was stored at $-70^{\circ} \mathrm{C}$ in $1-\mathrm{ml}$ aliquots. Premature serum was obtained from the cord blood of 18 healthy premature newborns whose mean gestational age and mean birth wt were $33 \mathrm{wk}$ and $1775 \mathrm{~g}$, respectively. Premature serum was pooled and stored in $1-\mathrm{ml}$ aliquots at $-70^{\circ} \mathrm{C}$. Heat inactivation to abolish complement activity was carried out at $56^{\circ} \mathrm{C}$ for $30 \mathrm{~min}$ to produce heat-inactivated adult serum and heat-inactivated premature serum. These heat-inactivated sera showed no complement activity when tested in the total hemolytic complement 
assay described below. Absorption to remove specific antibody was carried out by incubation of $10^{10} \mathrm{CFU}$ of homologous organisms per ml of serum at $4^{\circ} \mathrm{C}$ for $1 \mathrm{~h}$. The absorbed sera showed little specific antibody response by an indirect immunofluorescence assay detailed below, but preserved essentially normal complement activity. All of these serum preparations were stored at $-70^{\circ} \mathrm{C}$ until use. Zymosan treatment of serum (4 $\mathrm{mg} / \mathrm{ml}$ at $37^{\circ} \mathrm{C}$ for $40 \mathrm{~min}$; Sigma Chemical Co., St. Louis, MO) was used to study the CCP activity $(10,11) . \mathrm{Mg}^{++}$-EGTA-treated serum (10 mM of $\mathrm{MgCl}_{2}$ and EGTA; Sigma) was used to study ACP activity (12).

Assays of complement activity. $\mathrm{CH}_{50}$ and $\mathrm{AP}_{50}$ were measured in units of complement at the $50 \%$ hemolysis level of antibodysensitized sheep erythrocytes and unsensitized rabbit red blood cells, respectively (13). Both complement pathway activities were examined for each serum preparation.

Detection of specific antibodies and $C 3$ deposition. Specific antibodies against individual strains of bacteria as well as complement deposition on the bacteria were measured by an indirect immunofluorescence assay (14). Bacteria $\left(2 \times 10^{8} \mathrm{CFU} / \mathrm{ml}\right)$ were preopsonized with different dilutions $(1 / 2,1 / 4, \ldots$, to $1 / 256)$ of the serum preparations at $37^{\circ} \mathrm{C}$ for $30 \mathrm{~min}$. Bacteria were opsonized with absorbed serum in the presence or absence of IGIV $(5 \mathrm{mg})$ to study the effect of IGIV on complement deposition. Opsonized bacteria were washed and suspended to $2 \times 10^{8} \mathrm{CFU} / \mathrm{ml}$ in PBS. Each $\mathrm{ml}$ of preopsonized bacteria was reacted with $100 \mu \mathrm{l}$ of $1 / 5$ diluted fluorescein-conjugated goat anti-human IgG, C3, or IgM antibody (Cappel, Cooper Biomedicals Inc., Malvern, PA) for 15 min at room temperature. The bacterial suspensions were washed three times and resuspended to $1 \mathrm{ml}$ in PBS. The fluorescence of the second antibodies attached to the bacterial surface was quantitatively detected with a fluorimeter (LS-2B filter, PerkinElmer, Beaconsfield, England) set at 485 and $525 \mathrm{~nm}$ wavelengths. The results were expressed as arbitrary units (15).

Separation of neutrophils. Venous blood from healthy donors was drawn into plastic syringes containing $10 \mathrm{IU} / \mathrm{ml}$ of heparin. Dextran (3\%, T500; Pharmacia Fine Chemicals, Piscataway, NJ) was added in a ratio of $1 / 5$, and the syringe was incubated nozzle upward at $37^{\circ} \mathrm{C}$ for $30 \mathrm{~min}$. The upper fraction of leukocyteenriched plasma was then layered onto Ficoll-Paque (Pharmacia) at a ratio of $2: 1$ and was centrifuged at $1500 \times \mathrm{g}$ for $10 \mathrm{~min}$. The supernatant was discarded and the pellet was washed, while residual erythrocytes were lysed with $0.83 \%$ of ammonium chloride. The neutrophils were finally suspended to $10^{7}$ cells $/ \mathrm{ml}$ in HBSS. Using this method the purity and viability of neutrophils were consistently more than 95 and $98 \%$, respectively.

Opsonization of bacteria. Radiolabeled bacteria $\left(2 \times 10^{8} \mathrm{CFU}\right)$ were opsonized at $37^{\circ} \mathrm{C}$ for $30 \mathrm{~min}$ in $100 \mu \mathrm{l}$ of different serum preparations in the presence or absence of $100 \mu \mathrm{l}(5 \mathrm{mg})$ of IGIV (Gamimune N, Cutter Biological, Berkeley, CA). As indicated to study the interaction between IGIV and complement, the opsonization mixture included 1,5 , or $10 \%(0.5,2.5$, or $5 \mathrm{mg} / \mathrm{ml})$ IGIV in the presence of different concentrations of complement (absorbed adult or premature serum). The final reaction volume was made up in HBSS to a total of $1 \mathrm{ml}$. After opsonization, the bacteria were washed three times and resuspended at $2 \times 10^{8}$ organisms per $\mathrm{ml}$ in HBSS. For the intracellular killing assay (detailed below), the bacteria were not radiolabed and the preopsonized bacterial suspension was diluted to $2 \times 10^{7} \mathrm{CFU} / \mathrm{ml}$.

Opsonophagocytic assay. A radioisotope phagocytic assay was performed as previously described (16). A total of $1 \mathrm{ml}$ of the reaction mixture was set up in duplicate microcentrifuges containing 1) $100 \mu \mathrm{l}$ of opsonized bacteria $\left.\left(2 \times 10^{8} \mathrm{CFU} / \mathrm{ml}\right), 2\right)$ $100 \mu l$ of neutrophil suspension $\left(1 \times 10^{7}\right.$ cells $\left./ \mathrm{ml}\right)$, and 3$)$ HBSS. The bacteria to neutrophil ratio was $20: 1$ in all experiments and the reactions were incubated at $37^{\circ} \mathrm{C}$ and rotated end over end for $15 \mathrm{~min}$. At the end of the incubation period, extracellular bacteria were washed away by three cycles of differential centrifugation at $160 \times \mathrm{g}$ at $4^{\circ} \mathrm{C}$ for $4 \mathrm{~min}$. The cell pellet was suspended in $4 \mathrm{ml}$ scintillation liquid (Ultraflour, National Diagnostics, NJ) and counted in a Beckman LS1801 scintillation counter (Beck- man Instruments, Inc., Fullerton, CA). The opsonophagocytic activity was expressed by an opsonophagocytic index (OPI) defined as a percentage of the cell-associated bacteria in relation to the total bacteria added at time zero (OPI $=\mathrm{cpm}$ of cellassociated bacteria/cpm of total bacteria in the reaction $\times 100 \%$ ).

Purification of $F\left(a b^{\prime}\right)_{2}$ from IGIV. $\mathrm{F}\left(\mathrm{ab}^{\prime}\right)_{2}$ fragments were purified from pepsin-treated IGIV by a modification of a technique previously described (17). IGIV was digested with pepsin (Sigma) at the substrate to enzyme ratio of $50 / 1$. The reaction was carried out in $0.1 \mathrm{M}$ acetate buffer, $\mathrm{pH} 4.2$, at $37^{\circ} \mathrm{C}$ for 16 $h$. The $F\left(a b^{\prime}\right)_{2}$ fragments were further purified by gel filtration chromatography, using ULTROGEL AcA 44 (Pharmacia) to remove $\mathrm{Fc}$ fragments and intact $\mathrm{IgG}$. Fractions containing $\mathrm{F}\left(\mathrm{ab}^{\prime}\right)_{2}$ were pooled, dialyzed in PBS, and concentrated to $6 \mathrm{mg} /$ $\mathrm{ml}$. This pool contained no intact IgG or Fc fragments when analyzed by a 5 to $15 \%$ gradient SDS-PAGE (Fig. 1).

Intracellular killing assay. Inasmuch as the radioisotope phagocytic assay we used likely detects both attached and ingested bacteria by neutrophils, we also used an acridine orange/crystal violet microassay to simultaneously differentiate ingestion from attachment as well as intracellular killing. The assay was a modification of previously described procedures (18-20). One$\mathrm{ml}$ aliquots of neutrophils $\left(2 \times 10^{6} \mathrm{cells} / \mathrm{ml}\right)$ were pretreated with/without $10 \mu \mathrm{g} / \mathrm{ml}$ of anti-CR1 (44D) and/or anti-CR3 (Leu 15) MAb (Becton Dickinson, Inc., Mountain View, CA) at $4^{\circ} \mathrm{C}$ for $30 \mathrm{~min}$. The MAb, Leu 15, has been well characterized. AntiCR 1 antibodies produced by clone 44D have also been characterized by a number of investigators (21-23). This MAb (44D) is directed against $\mathrm{CR} 1$ receptors on erythrocytes, polymorpho-

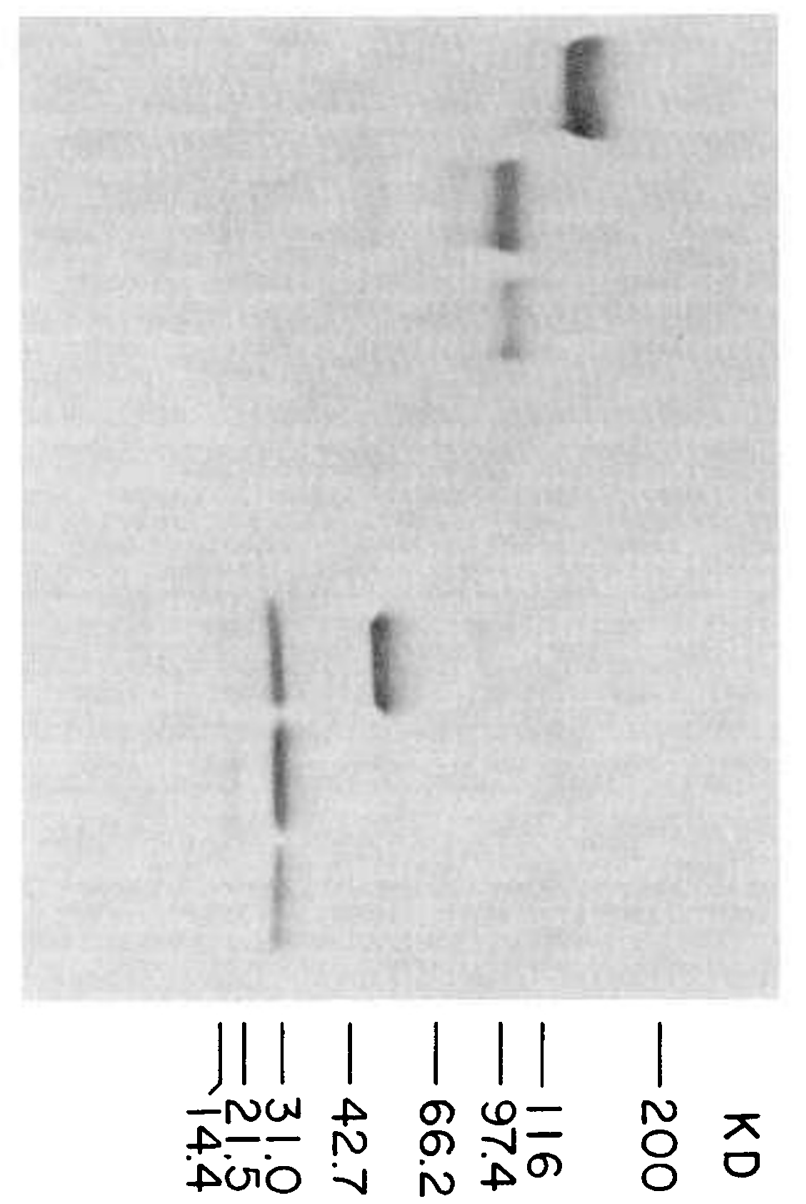

Fig. 1. Purity of $F\left(a b^{\prime}\right)_{2}$ as demonstrated by a $5-15 \%$ gradient SDSPAGE. Lanes $l$ and 4, IGIV (polyclonal IgG); lanes 2 and 5, pepsintreated IGIV; lanes 3 and $6, \mathrm{~F}\left(\mathrm{ab}^{\prime}\right)_{2}$ fragments purified from IGIV. Lanes $I$ to 3 , nonreduced samples, and lanes 4 to 6 : reduced samples (by $\beta$ mercaptoethanol). 
nuclear cells, mononuclear cells, and $\mathrm{T}$ lymphocytes, and specifically inhibit EAC3b rosette formation (21). Based on a preliminary study using a flow cytometric technique, this antibody concentration $(10 \mu \mathrm{g} / \mathrm{ml})$ was the optimal concentration for saturating complement receptors on neutrophils and did not affect neutrophil viability as determined by trypan blue exclusion. After washing, the suspensions were mixed with $1 \mathrm{ml}(2 \times$ $10^{7} \mathrm{CFU} / \mathrm{ml}$ ) of preopsonized $S$. aureus. Duplicate samples containing $0.5 \mathrm{ml}$ of the reaction mixture were then put on coverslips $\left(18 \times 18 \mathrm{~mm}^{2}\right)$ for 2 -h incubation at $37^{\circ} \mathrm{C}$. At the end of the incubation, the coverslips were washed and stained with $0.01 \%$ of acridine orange (Sigma) for $60 \mathrm{~s}$ followed by staining with $0.05 \%$ of crystal violet (Sigma) for $50 \mathrm{~s}$. After such staining, viable bacteria emitted green fluorescence while nonviable organisms emitted red fluorescence. Crystal violet, a large molecule that cannot enter neutrophils, quenches the fluorescence of all the bacteria remaining extracellular or membrane-adherent. Thus, the technique allows one to differentiate ingested from uningested or adherent organisms. In addition, the number of the intracellular viable (green) and nonviable (red) bacteria can be determined by the color of the fluorescence they emit. A phagocytic index (PI) was defined as the total number of intracellular bacteria (viable and nonviable) per 100 neutrophils. A bactericidal index (BI) was expressed as the total number of intracellular nonviable (red) bacteria per 100 neutrophils. Intracellular killing (ICK) was calculated from the number of intracellular dead (red) bacteria/total number of intracellular dead (red) and viable (green) bacteria $\times 100 \%(\mathrm{ICK}=\mathrm{BI} / \mathrm{PI} \times 100 \%)$.

\section{RESULTS}

Fluorescence measurement of specific serum antibodies. Using an immunofluoresence assay to detect the presence of serum antibodies interacting with the surface of the bacteria, we found that as the concentration of normal adult serum or premature serum increased, so did the amount of antibody bound to nonencapsulated $S$. aureus and $S$. enteritidis. The antibody titer in premature serum was lower than that of normal adult serum (Fig. 2). Specific antibodies against encapsulated $S$. pyogenes and $E$. col $i$ in normal adult serum were only detectable up to titers of $1: 8$ and 1:16, respectively. Little specific antibodies against these two encapsulated organisms could be measured in prema-
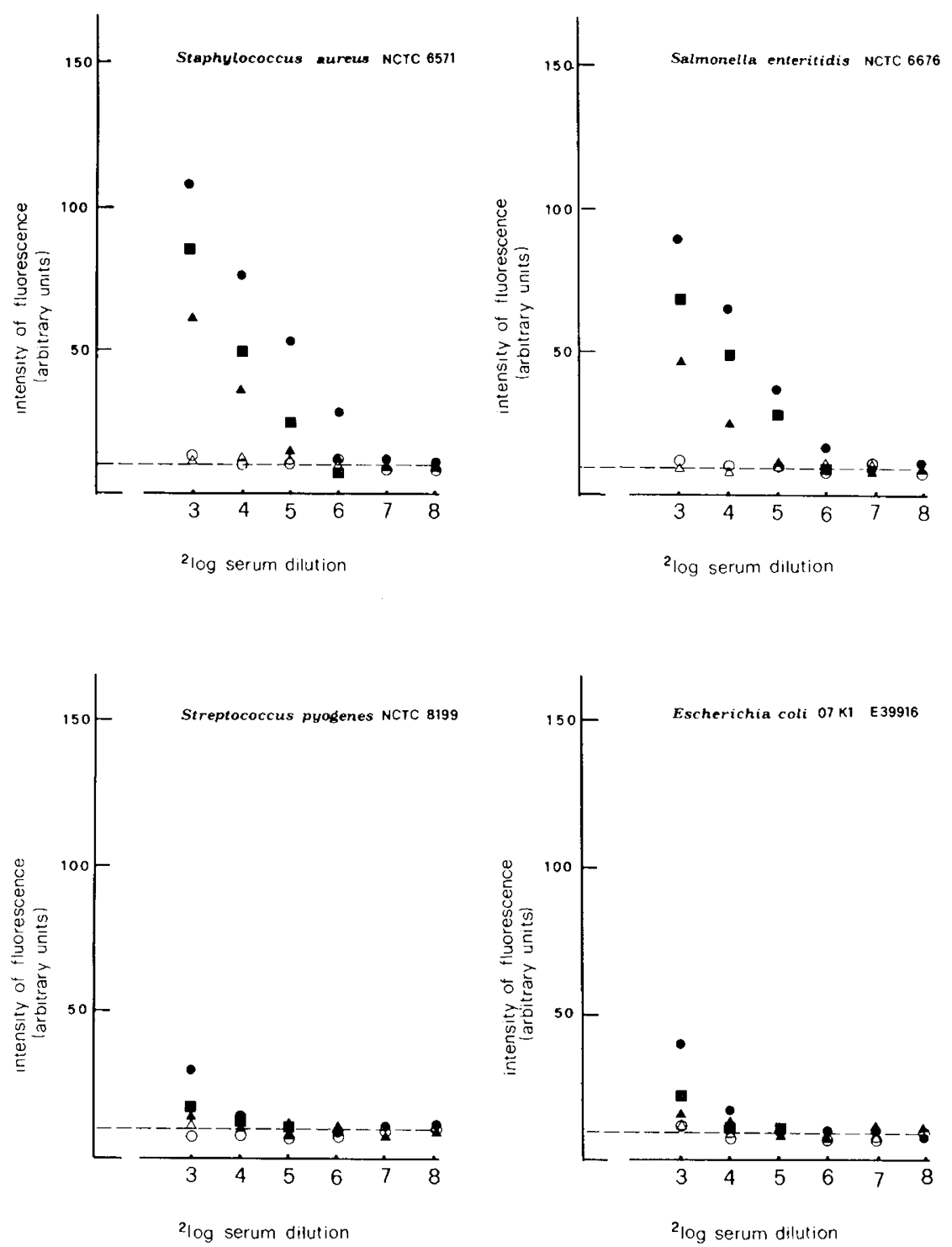

Fig. 2. Specific antibody titers to the bacteria in different serum preparations and IGIV determined by an indirect immunofluorescence assay. Fluorescent intensity of HBSS was used as baseline control (dashed line). Data are presented for normal adult serum (solid circles), absorbed adult serum (open circles), premature serum (solid triangles), absorbed premature serum (open triangles), and IGIV (solid squares). Data presented were generated from the means of five separate experiments. 
ture serum (Fig. 2). IGIV was also analyzed for its content of antibody to the four strains of bacteria (Fig. 2). It contained antibody titers of 1:32 for both nonencapsulated bacteria and of $1: 8$ for the two encapsulated bacteria. Absorbed premature and adult sera showed little specific antibody to these organisms (Fig. 2). Normal adult serum had a low IgM titer (1:2) against these two strains of nonencapsulated bacteria and no detectable IgM against the two strains of encapsulated organisms. IgM antibodies against these four organisms in premature serum were undetectable, as expected.

Complement activity in different serum preparations. As assessed by hemolytic units of complement, complement activity in premature serum was much lower than that in normal adult serum. $\mathrm{CH}_{50}$ in premature serum was $41 \%$ of that in normal adult serum and $\mathrm{AP}_{50}$ was only $26 \%$ of that in normal adult serum (Table 1). Properdin-depleted serum prepared by absorption with zymosan completely abolished $\mathrm{AP}_{50}$ but retained $80 \%$ of $\mathrm{CH}_{50} ; \mathrm{Mg}^{++}$EGTA-treated serum had essentially normal $\mathrm{AP}_{50}$ activity but no $\mathrm{CH}_{50}$ activity (Table 1).

Effect of IGIV on opsonic activities of different serum preparations. Different serum preparations were next used to opsonize the bacteria for phagocytosis by neutrophils. Normal adult serum clearly had greater opsonic capacity than did premature serum (Table 2). This was observed consistently with each of the four strains of bacteria tested. The opsonic activities of premature serum for $S$. aureus and $S$. enteritidis were greatly enhanced by the addition of IGIV $(P<0.001)$. In contrast, addition of IGIV did not alter the opsonic activity of normal adult serum against any strain of the bacteria tested (Table 2). $S$. pyogenes and $E$. coli strongly resisted opsonization by premature serum or normal adult serum in which there was no detectable specific IgM antibody or only low titers of specific IgG antibodies against these two strains of bacteria (Table 2; Fig. 2). Diminished opsonic activities against all the bacteria tested were noted in the absorbed premature and absorbed adult sera. Restoration of the diminished opsonic activity by the addition of IGIV was accomplished for the nonencapsulated bacteria, but not the encapsulated bacteria (Table 2). Both heat-inactivated premature and heat-inactivated adult sera resulted in a remarkable reduction in the opsonophagocytosis of these bacteria by neutrophils. Addition of IGIV did not improve the opsonic activity in the heatinactivate sera for any strain of the bacteria tested. In addition, IGIV alone had no opsonic activity (Table 2). These data indicated that antibody alone did not cause optimal opsonization unless complement was also present.

We examined further the interaction between IGIV and complement. The minimal concentration of complement necessary to achieve satisfactory opsonization of $S$. aureus at high concentration of antibody was 6-10\% (Fig. 3, left). At this concentration of complement, heat-inactivated adult serum alone could reconstitute optimal opsonization of $S$. aureus (Fig. 3, left). In contrast, higher concentrations of antibody produced by the addition of IGIV $(5 \mathrm{mg} / \mathrm{ml})$ to heat-inactivated premature serum were required to accomplish adequate opsonization of the organism by

Table 1. Hemolytic complement activity in different serum preparations*

\begin{tabular}{lcc}
\hline \multicolumn{1}{c}{ Serum preparations } & \multicolumn{1}{c}{$\mathrm{CH}_{50}$} & \multicolumn{1}{c}{$\mathrm{AP}_{50}$} \\
\hline Normal adult serum (NAS) & $196 \pm 33$ & $224 \pm 28$ \\
Premature serum (PS) & $81 \pm 16$ & $58 \pm 9$ \\
Zymosan-treated NAS & $163 \pm 41$ & 0 \\
Zymosan-treated PS & $64 \pm 13$ & 0 \\
$\mathrm{Mg}^{++}$EGTA-treated NAS & 0 & $236 \pm 21$ \\
$\mathrm{Mg}^{++}$EGTA-treated PS & 0 & $55 \pm 11$ \\
\hline
\end{tabular}

* Data are presented as mean $\pm \mathrm{SD}$ calculated by five duplicate experiments. $\mathrm{CH}_{50}$ and $\mathrm{AP}_{50}$ were measured by hemolytic titration using antibody-sensitized sheep red blood cells and unsensitized rabbit erythrocytes, respectively.
Table 2. Effects of IGIV on opsonization of bacteria by different serum preparations as measured by opsonophagocytosis*

\begin{tabular}{lrrr}
\hline Bacteria & \multicolumn{2}{c}{ Opsonophagocytic index } & \\
\cline { 2 - 3 } serum preparations & No IGIV & With IGIV & $p$ \\
\hline S. aureus & & & \\
NAS & $92.3 \pm 4.1$ & $91.1 \pm 6.3$ & NS \\
PS & $37.5 \pm 7.6$ & $92.4 \pm 3.5$ & $<0.001$ \\
AAS & $45.1 \pm 3.8$ & $90.6 \pm 4.2$ & $<0.001$ \\
APS & $17.6 \pm 5.4$ & $91.8 \pm 4.6$ & $<0.001$ \\
HAS & $6.4 \pm 1.7$ & $7.1 \pm 2.1$ & NS \\
HPS & $3.2 \pm 1.4$ & $3.5 \pm 1.8$ & NS \\
HBSS & $2.9 \pm 1.1$ & $2.8 \pm 1.2$ & NS \\
S. enteritidis & & & \\
NAS & $84.7 \pm 6.3$ & $86.2 \pm 6.4$ & NS \\
PS & $31.6 \pm 3.9$ & $85.8 \pm 5.6$ & $<0.001$ \\
AAS & $40.4 \pm 4.5$ & $85.3 \pm 4.1$ & $<0.001$ \\
APS & $15.1 \pm 3.8$ & $84.1 \pm 5.5$ & $<0.001$ \\
HAS & $7.1 \pm 1.4$ & $7.7 \pm 2.3$ & NS \\
HPS & $2.9 \pm 1.7$ & $2.4 \pm 2.0$ & NS \\
HBSS & $2.2 \pm 1.2$ & $1.9 \pm 0.7$ & NS \\
S. pyogenes & & & \\
NAS & $4.8 \pm 2.3$ & $5.2 \pm 1.9$ & NS \\
PS & $1.2 \pm 0.7$ & $1.6 \pm 0.8$ & NS \\
AAS & $1.8 \pm 1.4$ & $2.1 \pm 1.6$ & NS \\
APS & $0.8 \pm 0.6$ & $1.1 \pm 0.9$ & NS \\
HAS & $0.8 \pm 0.7$ & $0.9 \pm 0.5$ & NS \\
HPS & $0.9 \pm 0.3$ & $1.2 \pm 0.9$ & NS \\
HBSS & $0.8 \pm 0.4$ & $0.7 \pm 0.5$ & NS \\
E. coli $07 K I$ & & & \\
NAS & $4.9 \pm 2.5$ & $5.3 \pm 3.1$ & NS \\
PS & $1.9 \pm 1.2$ & $2.1 \pm 1.6$ & NS \\
AAS & $2.1 \pm 1.5$ & $1.9 \pm 1.3$ & NS \\
APS & $0.9 \pm 0.5$ & $1.1 \pm 0.7$ & NS \\
HAS & $1.1 \pm 0.8$ & $1.6 \pm 0.9$ & NS \\
HPS & $0.8 \pm 0.8$ & $0.9 \pm 0.5$ & NS \\
HBSS & $0.8 \pm 0.4$ & $0.9 \pm 0.8$ & NS \\
\hline
\end{tabular}

* Data are expressed as mean \pm SD from five duplicate experiments. $p$ is calculated by Student's $t$ test. NS, not significant; NAS, normal adult serum; PS, premature serum; AAS, absorbed adult serum; APS, absorbed premature serum; HAS, heat-inactivated adult serum; HPS, heat-inactivated premature serum.

complement in the absorbed premature serum (Fig. 3, right). These results indicate that increasing levels of specific antibodies in the premature serum results in complement mediated opsonic activity matching that in normal adult serum even though $\mathrm{CH}_{50}$ and $\mathrm{AP}_{50}$ in premature serum were only one half and one quarter, respectively, of those in normal adult serum (Table 1).

Effects of IGIV on bacterial opsonization by both complement pathways. The opsonic activity of premature serum for $S$. aureus and $S$. enteritidis was enhanced by the addition of IGIV (Table 2). We next investigated the effect of IGIV on opsonophagocytosis of these two strains of bacteria by both complement pathways in premature serum. The opsonic activity for $S$. aureus and $S$. enteritidis by the classic complement pathway in premature serum was only 37 and $40 \%$ of that in normal adult serum, whereas the activity of the alternative pathway in premature serum was 24 and $20 \%$ of that in normal adult serum. Addition of IGIV did not increase the opsonic activity of either the classic or alternative pathway in normal adult serum, but it did significantly enhance the opsonic activity of both pathways in premature serum, especially the alternative pathway (Table 3 ).

Effect of IGIV on complement deposition on bacteria. Triggering of complement produces opsonic C3 fragments. Using a fluorescein-conjugated goat anti-human $\mathrm{C} 3$ antibody, we found that addition of IGIV significantly enhanced C3 deposition on $S$. aureus and $S$. enteritidis by both complement pathways in 


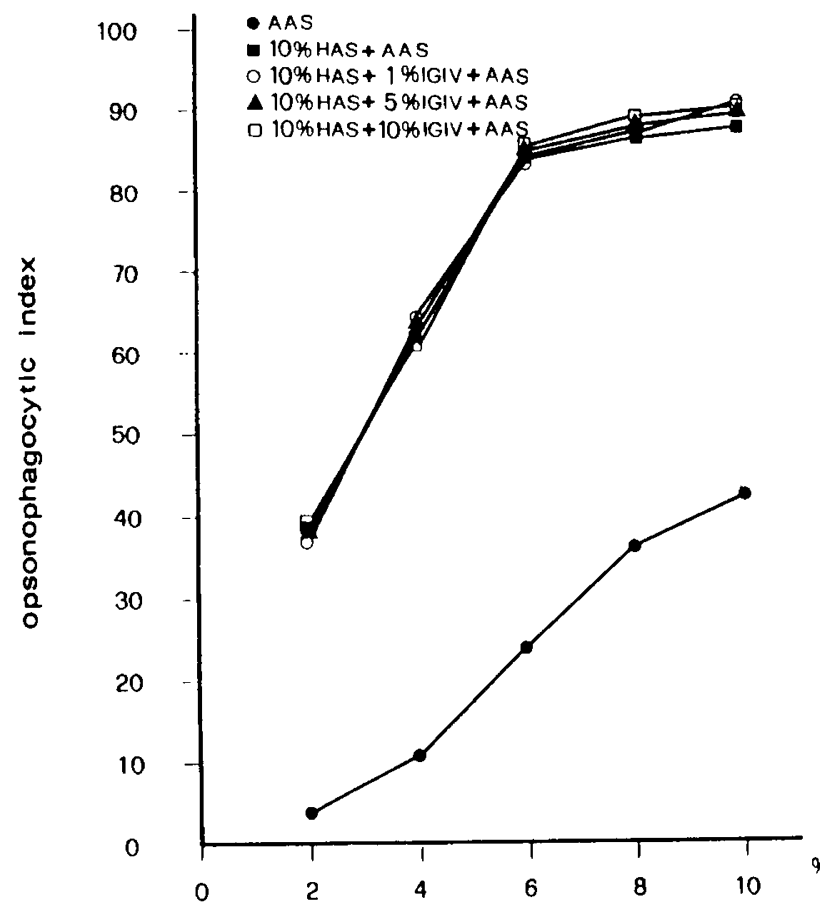

concentration of absorbed adult serum

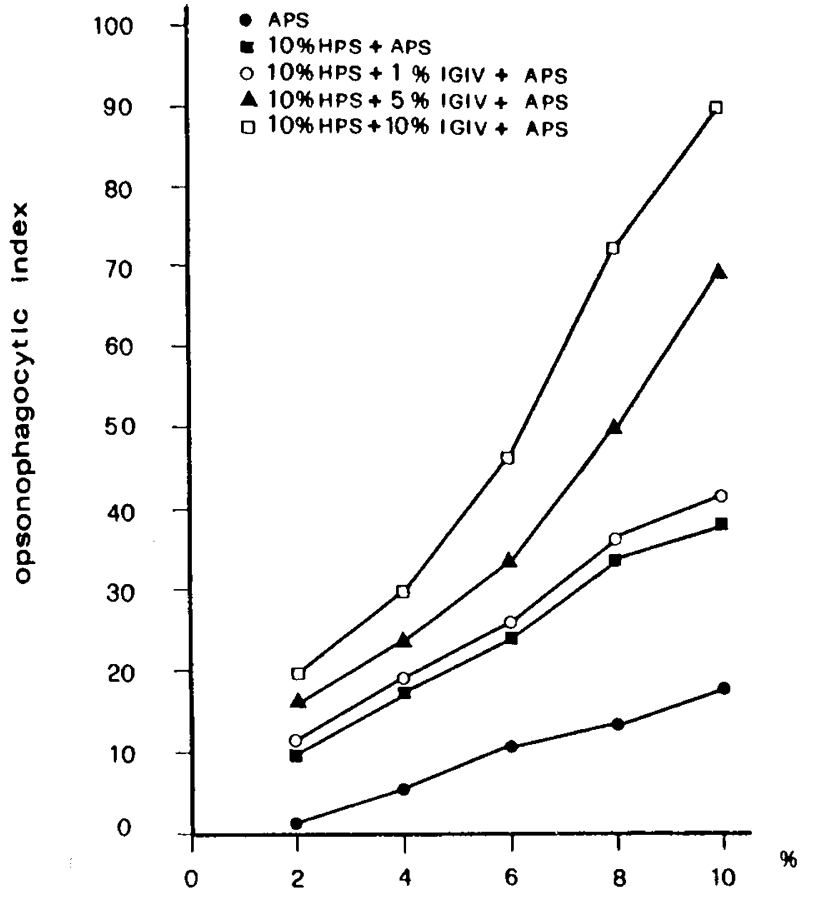

concentration of absorbed premature serum

Fig. 3. Effects of IGIV on the complement-dependent opsonization of $S$. aureus. Left, heat-inactivated adult serum $(H A S)$ alone could reconstitute optimal opsonization at $6-10 \%(\mathrm{v} / \mathrm{v})$ absorbed adult serum $(A A S)$. Right, a higher concentration of IGIV $(5 \mathrm{mg} / \mathrm{ml})$, in addition to heat-inactivated premature serum (HPS), was required to accomplish optimal opsonization at $10 \%$ absorbed premature serum (APS). Data are plotted by the means of three duplicate experiments.

Table 3. Effects of IGIV on opsonization of bacteria by both complement $\left(C^{\prime}\right)$ pathways*

\begin{tabular}{|c|c|c|c|c|}
\hline \multirow{3}{*}{$\begin{array}{c}\text { Serum } \\
C^{\prime} \text { pathway }\end{array}$} & \multicolumn{4}{|c|}{ Opsonophagocytic index } \\
\hline & \multicolumn{2}{|c|}{ S. aureus } & \multicolumn{2}{|c|}{ S. enteritidis } \\
\hline & No IGIV & With IGIV & No IGIV & With IGIV \\
\hline \multicolumn{5}{|l|}{ NAS } \\
\hline $\mathrm{CCP}$ & $38.3 \pm 4.8$ & $40.1 \pm 6.1$ & $18.2 \pm 3.8$ & $19.6 \pm 4.6$ \\
\hline $\mathrm{ACP}$ & $21.5 \pm 2.6$ & $19.2 \pm 3.2$ & $33.7 \pm 4.4$ & $32.4 \pm 5.3$ \\
\hline \multicolumn{5}{|l|}{ PS } \\
\hline $\mathrm{CCP}$ & $13.4 \pm 2.5$ & $27.6 \pm 5.4 \dagger$ & $7.3 \pm 1.1$ & $11.7 \pm 2.8 \dagger$ \\
\hline $\mathrm{ACP}$ & $5.1 \pm 2.7$ & $20.8 \pm 2.9 \ddagger$ & $6.9 \pm 1.4$ & $34.6 \pm 1.9 \ddagger$ \\
\hline
\end{tabular}

* Data presented are mean $\pm \mathrm{SD}$ determined by five separate experiments. NAS, normal adult serum; PS, premature serum.

$\dagger p<0.05$ between presence and absence of IGIV ( $t$ test).

$\ddagger p<0.001$ between presence and absence of IGIV ( $t$ test).

premature serum $(P<0.01)$, but did not augment $\mathrm{C} 3$ deposition on bacteria in normal adult serum (Fig. 4).

Effects of $F\left(a b^{\prime}\right)_{2}$ on complement-dependent phagocytosis and intracellular killing. As demonstrated by the radioisotope assay of phagocytic uptake, IGIV alone had no opsonic activity for these organisms. It did, however, enhance opsonophagocytosis in the presence of complement. Enhancement of opsonophagocytosis by the addition of IGIV may be mediated by complement receptors, $\mathrm{Fc}$ receptors, or both mechanisms. We found that $\mathrm{F}\left(\mathrm{ab}^{\prime}\right)_{2}$ fragments prepared from the IGIV enhanced uptake and killing of $S$. aureus by neutrophils only in the presence of complement (Table 4). This result suggests that $\mathrm{F}\left(\mathrm{ab}^{\prime}\right)_{2}$ fragments can trigger complement activation and result in phagocytosis through a complement-mediated mechanism. Neutrophils have two types of complement receptors, CR1 and CR3, on their surfaces. We blocked CR1 and/or CR3 with monoclonal anti-

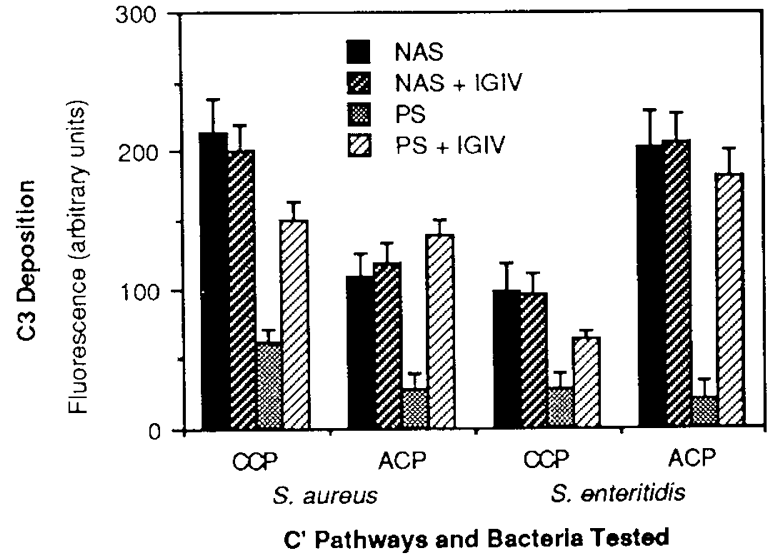

Fig. 4. Effects of IGIV on $\mathrm{C} 3$ deposition on bacteria through both complement pathways. Data are presented as mean \pm SD from three duplicate experiments. PS, premature serum; $N A S$, normal adult serum. Addition of IGIV significantly enhanced C3 deposition on $S$. aureus and $S$. enteritidis in PS $(P<0.01$; paired $t$ test $)$, but did not augment those in NAS.

bodies to examine the role of these complement receptors. Blockade of CR1 did not affect the opsonophagocytosis of S. aureus; blocking CR3 significantly inhibited both phagocytic and bactericidal indices of the bacteria by neutrophils (Table 4). Blocking these receptors did not, however, alter intracellular killing (Table 4). In addition, complement in combination with intact IgG (5 $\mathrm{mg} / \mathrm{ml}$ ) had a higher opsonic activity than did equimolar concentration $(3 \mathrm{mg} / \mathrm{ml})$ of $F\left(\mathrm{ab}^{\prime}\right)_{2}$ fragments (Table 4), indicating synergism between complement- and Fc receptor-dependent phagocytosis. 
Table 4. Effects of $F\left(a b^{\prime}\right)_{2}$ on complement-dependent phagocytosis and intracellular killing of S. aureus*

\begin{tabular}{|c|c|c|c|}
\hline Reactions & $\mathrm{BI}$ & PI & $\operatorname{ICK}(\%)$ \\
\hline$\overline{\mathrm{PMN}}+\overline{\text { S. aureus }}$ & $33.5 \pm 17.6$ & $46.0 \pm 18.4$ & $70.7 \pm 10.1$ \\
\hline $\mathrm{PMN}+$ S. aureus-C $\mathrm{C}^{\prime}$ & $78.5 \pm 7.8$ & $114.0 \pm 16.3$ & $68.7 \pm 2.9$ \\
\hline $\mathrm{PMN}+S$. aureus-IGIV & $40.0 \pm 7.1$ & $61.0 \pm 14.1$ & $66.0 \pm 3.7$ \\
\hline $\mathrm{PMN}+S$. aureus $-\mathrm{F}\left(\mathrm{ab}^{\prime}\right)_{2}$ & $39.5 \pm 16.3$ & $57.0 \pm 25.5$ & $69.7 \pm 2.5$ \\
\hline $\mathrm{PMN}+S$. aureus-C $-\mathrm{IGIV}$ & $233.0 \pm 34.0$ & $322.2 \pm 40.4$ & $72.1 \pm 2.3$ \\
\hline $\mathrm{PMN}+S$. aureus $-\mathrm{C}^{\prime}-\mathrm{F}\left(\mathrm{ab}^{\prime}\right)_{2}$ & $166.7 \pm 26.1$ & $229.7 \pm 28.0$ & $72.2 \pm 4.0$ \\
\hline $\mathrm{PMN}+$ anti-CR $1+S$. aureus $-\mathrm{C}^{\prime}-\mathrm{F}\left(\mathrm{ab}^{\prime}\right)_{2}$ & $164.8 \pm 27.5$ & $239.8 \pm 29.3$ & $68.6 \pm 5.2$ \\
\hline $\mathrm{PMN}+$ anti-CR3 + S. aureus- $\mathrm{C}^{\prime}-\mathrm{F}\left(\mathrm{ab}^{\prime}\right)_{2}$ & $103.5 \pm 29.1$ & $152.2 \pm 33.9$ & $67.6 \pm 6.5$ \\
\hline $\mathrm{PMN}+$ anti-CR $1, \mathrm{CR} 3+$ S. aureus-C $-\mathrm{F}\left(\mathrm{ab}^{\prime}\right)_{2}$ & $92.8 \pm 35.2$ & $133.0 \pm 43.7$ & $69.6 \pm 8.6$ \\
\hline
\end{tabular}

${ }^{*}$ Complement $\left(\mathrm{C}^{\prime}\right)$ source was $10 \%$ absorbed adult serum. BI, bactericidal index; PI, phagocytic index; ICK, intracellular killing. Preopsonization concentrations of $\mathrm{F}\left(\mathrm{ab}^{\prime}\right)_{2}$ and IGIV were 3 and $5 \mathrm{mg} / \mathrm{ml}$, respectively. Data are expressed as mean $\pm \mathrm{SD}$ calculated by three duplicate experiments.

\section{DISCUSSION}

Defective opsonization of bacteria by premature serum is due to lack of effective antibodies and low complement activity (5). In this study, we have demonstrated that the opsonic effects of premature serum on $S$. aureus and $S$. enteritidis can be increased by the addition of IGIV. We have also shown that IGIV enhances opsonization and C3 deposition by both complement pathways, especially the alternative pathway, in premature serum.

Activation of the complement system can occur via two pathways, both of which can be modulated by Ig (24). IGIV alone has little capacity to initiate nonspecific complement activation (25) and low opsonic activity when used alone against most of the common bacterial pathogens (9). In the presence of complement, IGIV markedly enhanced the opsonic activity against a variety of bacterial pathogens (9). In this study, we found that a high concentration of IGIV $(5 \mathrm{mg} / \mathrm{ml})$ was able to promote the opsonic activity in premature serum to a level matching that in normal adult serum (Fig. 3). This concentration of IGIV also augmented opsonic activity and $\mathrm{C} 3$ deposition on bacteria by both complement pathways in premature serum (Table 3; Fig. 4). Opsonization of bacteria that are alternative pathway activators is believed to be mediated by an antibody-independent route (26). Several studies, however, have shown that antibodies can also activate the alternative complement pathway (27-31). Nydegger and Kazatchkine (32), composing a schematic representation of the interaction between immune complexes and complement, have proposed that $\mathrm{C} 3 \mathrm{~b}$ is able to bind to the $\mathrm{F}\left(\mathrm{ab}^{\prime}\right)_{2}$ portion of antibody and trigger alternative pathway activation. In this study, we have also demonstrated that $F\left(a b^{\prime}\right)_{2}$ fragments of IGIV enhance phagocytosis of $S$. aureus only in the presence of complement. This $\mathrm{F}\left(\mathrm{ab}^{\prime}\right)_{2}$-enhanced phagocytosis can be largely blocked by MAb to complement receptors. These data further support the concept that $F\left(a b^{\prime}\right)_{2}$ fragments of IgG enhance complement deposition and phagocytosis through activation of the alternative pathway. Intact IgG, in the presence of complement, caused more phagocytosis than did equimolar amount of $\mathrm{F}\left(\mathrm{ab}^{\prime}\right)_{2}$ (Table 4), indicating that Fc-mediated mechanisms, either activation of complement, or interaction with $\mathrm{Fc}$ receptor, are required for most efficient opsonophagocytosis.

Employing an $\mathrm{AO} / \mathrm{CV}$ microassay that allows one to simultaneously assess actual ingestion as well as intracellular killing, we observed that $F\left(a b^{\prime}\right)_{2}$ fragments purified from the IGIV preparation elicited complement-mediated phagocytosis. We also demonstrated that CR3, but not CR1, was the major receptor for complement-mediated phagocytosis of $S$. aureus by neutrophils. These results are similar to those of Anderson et al. (33) that indicated phagocytic killing of $S$. aureus by neutrophils was significantly inhibited by anti-CR3 but not anti-CR 1 MAb. In addition, we found that blockade of CR1 and/or CR3 had no effect on intracellular killing of the organism by neutrophils.

As demonstrated by the quantitative immunofluoresence assay, specific IgG antibody titers against nonencapsulated bacteria in IGIV, premature serum, and normal adult serum were higher than those against encapsulated bacteria. In contrast, specific IgM antibodies against these organisms were not detectable in premature serum. In normal adult serum, there was a low IgM titer $(1: 2)$ for the nonencapsulated organisms but undetectable levels of IgM against the encapsulated strains of bacteria. IGIV enhanced the opsonic activity of premature serum against the nonencapsulated bacteria in the presence of complement (absorbed serum), but not that for the encapsulated bacteria (Table 2). Using human IgM purified from normal adult serum, we found that the IgM preparation did not promote opsonophagocytosis of these encapsulated and nonencapsulated bacteria in the presence of complement (data not shown). These studies suggested that optimal opsonization for these nonencapsulated bacteria was predominantly IgG-dependent. Poor opsonization for the encapsulated bacteria might be due to the lack of effective specific IgM antibody against the organisms in premature serum, normal adult serum, and the IGIV preparation. Not surprisingly, premature serum had undetectable specific IgM antibodies to these organisms because premature B cells have a limited ability to produce IgM antibody. The fact that normal adult serum had low or absent specific IgM antibodies against these organisms suggests that the donors had not been recently exposed to these organisms. Capsular polysaccharride often results in a primary immune response of the IgM class and little or no immunologic memory (26). Another possibility is that capsular antigen, such as the $\mathrm{K}$ antigen of $E$. coli, may inhibit complement activation and phagocytosis (34).

Although the IGIV preparation contained higher specific IgG antibodies against certain bacteria such as $S$. aureus and $S$. enteritidis (Fig. 2), these antibodies were not opsonic by themselves. As shown in Table 2, IGIV either alone or in combination with heat-inactivated adult or premature serum demonstrated no opsonic activities for the organisms. In contrast, IGIV or $\mathrm{F}\left(\mathrm{ab}^{\prime}\right)_{2}$ fragments purified from the IGIV preparation promoted opsonophagocytosis in the presence of complement. These data suggest that antibodies in the IGIV result in the activation of complement and the promotion of complement dependent phagocytosis. This is in agreement with the studies of Hill et al. (9) that showed IGIV alone had virtually no opsonic activity for most of the common bacterial pathogens. Furthermore, these authors found that the enhancement of bacterial opsonization by IGIV was correlated with the ability to consume complement by the IGIV-opsonized bacteria (23).

This study, therefore, indicates that supplementation of premature serum with an IGIV preparation containing higher titers of specific antibody enhances the opsonophagocytosis of bacteria primarily through an amplification of complement activation, especially the alternative pathway. This feature must be considered during the development of therapeutic regimens for the prevention and prophylaxis of sepsis with passive immunotherapy in the premature. 
Acknowledgment. The authors thank S. C. Kee for her research assistance and Don Morse for his artwork.

\section{REFERENCES}

1. Horwitz MA 1982 Phagocytosis of microorganisms. Rev Infect Dis 4:104-123

2. Buckley RH 1982 Long term use of intravenous immune globulin in patients with primary immunodeficiency disease: inadequacy of current dosage practices and approaches to the problem. J Clin Immunol 2(suppl):15-21

3. Ochs HD, Fisher SH, Wedgwood RJ 1982 Modified immune globulin: its use in the prophylactic treatment of patients with immune deficiency. J Clin Immunol 2(suppl):22-29

4. Wordell CJ 1987 Intravenous immune globulin: dosage and administration. Pharmacotherapy 7(suppl):27-30

5. Fleer A, Gerads LJ, Aerts P, Westerdaal NAC, Senders RC, van Dijk H, Verhoef J 1985 Opsonic defense to Staphylococcus epidermidis in the premature neonate. J Infect Dis 152:930-937

6. Haque KN, Zaidi MH, Haque SK, Bahakim H, El-Hazmi M, El-Swailam M 1986 Intravenous immunoglobulin for prevention of sepsis in preterm and low birth weight infants. Pediatr Infect Dis 5:622-625

7. Sidiropoulos D, Boehme U, Von Muralt G, Morell A, Barandun S 1986 Immunoglobulin supplementation in prevention or treatment of neonatal sepsis. Pediatr Infect Dis 5(suppl):193-194

8. Bortolussi R 1986 Potential for intravenous gamma-globulin use in neonatal gram negative infection: an overview. Pediatr Infect Dis 5(suppl):198-200

9. Hill HR, Augustine NH, Shigeoka AO 1984 Comparative opsonic activity of intravenous gamma globulin preparations for common bacterial pathogens. Am J Med 76 (suppl):61-66

10. Pillemer L, Blum L, Lepow IH, Wurz L, Todd EW 1956 The properdin system and immunity: (III) the zymosan assay of properdin. J Exp Med 103:1-13

11. Bortolussi R, Issekutz A, Faulkner G 1986 Opsonization of Listeria monocytogenes type $4 \mathrm{~b}$ by human adult and newborn sera. Infect Immun 52:493498

12. Fine DP, Marney SR Jr, Colley DG, Sergent JS, Des Prez RM 1972 C3 shunt activation in human serum chelated with EGTA. J Immunol 109:807-809

13. Whaley K 1985 Measurement of complement. In: Whaley K (ed) Methods in Complement for Clinical Immunologists. Churchill-Livingstone, Edinburgh, pp $77-104$

14. Verbrugh HA, van Dijk WC, van Erne ME, Peters R, Peterson PK, Verhoef J 1979 Quantitation of the third component of human complement attached to the surface of opsonized bacteria: opsonin-deficient sera and phagocytosisresistant strains. Infect Immun 26:808-812

15. Shaio MF, Rowland HAK 1985 Bactericidal and opsonizing effects of normal serum on mutant strains of Salmonella typhimurium. Infect Immun 49:647653

16. Peterson PK, Verhoef J, Schmeling D, Quie PG 1977 Kinetics of phagocytosis and bacterial killing by human polymorphonuclear leukocytes and monocytes. J Infect Dis 136:502-509

17. Gorevic PD, Prelli FC, Frangione B 1985 Immunoglobulin G. In: Sabato GD,
Langone JJ, Vunakis HV (eds) Methods in Enzymology, Vol 116. Academic Press, Inc., New York, pp 16-18

18. Smith DL, Rommel F 1977 A rapid micromethod for the simultaneous determination of phagocytic-microbiocidal activity of human peripheral blood leukocytes in vitro. J Immunol Methods 17:241-247

19. Farkas-Himsley H, Kormendy A, Kormendy JF, Beaver S 1985 Microassay to monitor bacterial phagocytosis. Lab Med 16:164-167

20. Allred CD, Shigeoka AO, Hill HR 1979 Evaluation of group B streptococcal opsonins by radiolabeled bacterial uptake. J Immunol Methods 26:355-363

21. Iida K, Mornaghi R, Nussenzweig V 1982 Complement receptor (CR1) deficiency in erythrocytes from patients with systemic lupus erythematosus. J Exp Med 155:1427-1438

22. Gaither TA, Gallin JI, lida K, Nussenzweig V, Frank MM 1984 Deficiency in $\mathrm{C} 3 \mathrm{~b}$ receptors on neutrophils with chronic granulomatous disease and hyperimmunoglobulin-E recurrent infection (Job's) syndrome. Inflammation 8:429-444

23. Yang KD, Bathras JM, Shigeoka AO, James J, Pincus SH, Hill HR 1989 Mechanisms of bacteria opsonization by immune globulin intravenous: Correlations of complement consumption with opsonic activity and protective efficacy. $J$ Infect Dis (in press)

24. Brown EJ, Joiner KA, Frank MM 1983 The role of complement in host resistance to bacteria. Springer Semin Immunopathol 6:349-360

25. Bing DH 1984 Complement interaction with immune serum globulin and immune globulin intravenous. Am J Med 76 (suppl): 19-24

26. Cooper NR 1987 The complement system. In: Stites DP, Stobo JD, Wells JV (eds) Basic And Clinical Immunology 6th ed. Appleton \& Lange, Inc., East Norwalk, CT, pp 114-127

27. Edwards MS, Nicholson-Weller A, Baker CJ, Kasper DL 1980 The role of specific antibody in alternative complement pathway-mediated opsonophagocytosis of type III, group B Streptococcus. J Exp Med 151:1275-1287

28. Edwards MS, Kasper DL, Jennings HJ, Baker CJ, Nicholson-Weller A 1982 Capsular sialic acid prevents activation of the alternative complement pathway by type III, group B streptococci. J Immunol 128:1278-1283

29. Ratnoff WD, Fearon DT, Austen KF 1983 The role of antibody in the activation of the alternative complement pathway. Springer Semin Immunopathol $6: 361-371$

30. Steele NP, Munson RS Jr, Granoff DM, Cummins JE, Levine RP 1984 Antibody-dependent alternative pathway killing of Haemophilus influenzae type b. Infect Immun 44:452-458

31. Eisenberg RA, Schwab JH 1986 Arthropathic group A streptococcal cell walls require specific antibody for activation of human complement by both the classic and alternative pathways. Infect Immun 53:324-330

32. Nydegger UE, Kazatchkine MD 1986 Modulation by complement of immune complex processing in health and disease in man. Progr Allergy 39:361-392

33. Anderson DC, Miller LJ, Schmalstieg FC, Rothlein R, Springer TA 1986 Contributions of the Mac-1 glycoprotein family to adherence-dependent granulocyte functions: structure-function assessments employing subunitspecific monoclonal antibodies. J Immunol 137:15-27

34. Thirumoorthi MC, Dajani AS 1982 Diseases caused by Escherichia coli. In Wedgwood RJ, Davis SD, Ray CG, Kelley VS (eds) Infections in Children. Harper \& Row, Inc., Philadelphia, pp 856-864 